\title{
PENERAPAN MEDIA KARIKATUR BERBASIS SPARKOL VIDEO SCRIBE UNTUK MENINGKATKAN HASIL BELAJAR KOGNETIF PADA MATAKULIAH GENETIKA MAHASISWA BIOLOGI KALAS-A ANGKATAN 2014-IBU
}

\author{
Riyanto $^{1}$, As'ad Samsul Arifin ${ }^{2}$, Boby Ardiyansah ${ }^{3}$ \\ 1,2, ${ }^{3}$ IKIP Budi Utomo Malang, Jl. Citandui 46, Kota Malang \\ e-mail: riyanto.arkum.27.83@gmail.com
}

\begin{abstract}
Penelitian ini bertujuan untuk mengetahui peningkatan hasil belajar kognetif melalui media karikatur berbasis sparkol video scribe pada matakuliah Genetika mahasiswa Pendidikan Biologi 2014-A IKIP Budi Utomo Malang (IBU). _Jenis penelitian ini adalah Penelitian Tindakan Kelas (PTK) dengan rancangan berupa pemberian tindakan pada siklus pembelajaran, yang dilaksanakan dalam 2 siklus. Subjek dalam penelitian ini adalah mahasiswa Biologi kelas A angkatan 2014, berjumlah 38 mahasiswa. Proses pengumpulan data penelitian dilaksanakan dengan langkah-langkah, yaitu mengobservasi keaktifan mahasiswa dalam proses belajar mengajar dan pelaksanaan tes formatif pada tiap akhir siklus dilanjutkan dengan analisis hasil tes. Teknik analisis data menggunakan analisis persentase, yang mana ranah analisisnya meliputi analisis keaktifan mahasiswa dalam proses belajar mengajar dan analisis hasil belajar kognetif mahasiswa. Berdasarkan hasil penelitian, dapat disimpulkan bahwa ketuntasan klasikal hasil belajar berupa tes siklus I termasuk ke dalam kategori 'Cukup' karena mampu mencapai 71\% dengan rata-rata hasil tes adalah 68 , namun persentase tersebut belum mampu mencapai target ketuntasan klasikal minimal $80 \%$, oleh karena itu peneliti melanjutkan tindakan pada siklus II. Hasil Penelitian Tindakan Kelas siklus II menunjukkan ketuntasan klasikal hasil belajar berupa tes termasuk ke dalam kategori 'Baik' karena mampu mencapai $82 \%$ dengan rata-rata hasil tes adalah 73,6 , dan persentase ketuntasan ini telah melewati standar ketuntasan klasikal minimal $80 \%$. Keaktifan mahasiswa dalam proses belajar mengajar pun meningkat dari siklus ke siklus, yaitu rata-rata persentase mahasiswa yang aktif pada siklus I hanya mencapai $44,21 \%$, sedangkan pada siklus II meningkat menjadi $58,42 \%$. Sesuai dengan hasil analisis data tersebut maka dapat disimpulkan bahwa melalui media karikatur berbasis sparkol video scribe dapat meningkatkan hasil belajar kognetif mahasiswa Biologi kelas A angkatan 2014 IKIP Budi Utomo Malang.
\end{abstract}

Keyword: Media Karikatur berbasis sparkol video scribe, Hasil belajar kognetif..

\section{PENDAHULUAN}

Association for Education and Communication Technology (AECT), mendifinisikan media sebagai segala bentuk dan saluran yang dipergunakan untuk proses informasi. National Education Association (NEA) mengartikan media sebagai segala benda yang dapat dimanipulasikan, dilihat, didengar, dibaca atau dibicarakan beserta instrumen yang dipergunakan untuk kegiatan 
tersebut (Muhson, 2010). Bretz (dalam Sanaky, 2009) mengidentifikasi ciri utama dari media menjadi tiga unsur pokok, yaitu visual, suara, dan gerak. Visual dibedakan menjadi tiga yaitu garis, gambar, dan simbol yang merupakan suatu kontinum dari bentuk yang dapat ditangkap dengan indera penglihatan. Di samping itu, Bretz juga membedakan antara media siar (telecommunication) dan media rekam (recording) sehingga terdapat delapan klasifikasi media: (1) media audio visual gerak, (2) media audio visual diam, (3) media audio visual semi gerak, (3) media visual gerak, (5) media visual diam, (6) media semi gerak, (7) media audio, dan (8) media cetak.

Media pembelajaran merupakan salah satu komponen pembelajaran yang mempunyai peranan penting dalam proses perkuliahan. Pemanfaatan media seharusnya merupakan bagian yang harus mendapat perhatian dosen dalam setiap kegiatan perkuliahan. Secara umum, manfaat media dalam proses perkuliahan adalah memperlancar hubungan timbal balik antara dosen dan mahasiswa sehingga kegiatan pembelajaran menjadi lebih inovatif dan partisipatif.

IKIP Budi Utomo Malang adalah salah satu LPTK yang bertugas menyiapkan colon pendidik di berbagai jenis program studi, jenjang (S1, S2). Di dalam peranannya dalam dunia pendidikan IKIP Budi Utomo malang senantiasa berusaha untuk melakukan sebuah pembaharuan pendidikan melalui berbagai riset kependidikan hal tersebut dimaksudkan agar dapat mengembangkan konsep pembelajaran serta untuk mengupdate sistem pembelajaran yang inovatif dengan penggunaan media pemebelajaran interaktif. Dimana seiring perkembangan zaman tuntutan pendidikan akan kualitas SDM semakin menjadi sorotan publik.
Berdasarkan hasil observasi dan pengamatan yang telah di lakukan peneliti di lapangan khususnya di IKIP Budi Utomo Malang hasil belajar kognetif mahasiswa masih rendah terutama sangat terlihat pada pembelajaran mata kuliah genetika. Tercatat bahwa $60 \%$ mahasiswa masih menganggap bahwa mata kuliah genetika adalah pembelajaran yang sangat sulit dipahami dan dimengerti, sehingga menyebabkan mahasiswa menjadi kurang termotivasi dalam belajar genetika dan akhirnya mengakibatkan hasil belajar kognetif mahasiswa menjadi rendah.

Mengingat sulitnya materi dan belum dingunakannya media Pembelajaran Inovatif maka diperlukan adanya inovasi pembelajaran salah satunya dengan menggunakan media karikatur berbasis sparkol video scribe. Sparkol videoscribe adalah software yang bisa kita gunakan dalam membuat desain animasi berlatar putih dengan sangat mudah. Whiteboard animation merupakan media komunikasi yang dibuat oleh pengirim kepada penerima tanda melalui simbolsimbol yang ada di whiteboard animation.

Penerapan media karikatur berbasis sparkol video scribe diharapkan dapat menciptakan iklim belajar yang menyenangkan, menarik perhatian mahasiswa dan dapat meningkatkan hasil belajar kognetif mahasiswa Biologi Kelas A angkatn 2014 IKIP Budi Utomo Malang. Berdasarkan latar belakang diatas, serta perlu ditingkatkannya hasil belajar kognetif mahasiswa pada matakuliah Genetika, maka pelu dilakukan penelitian tentang "Penerapan Media Karikatur Berbasis Sparkol Video Scribe Pada Mata Kuliah Genetika Untuk Meningkatkan Hasil Belajar kognetif mahasiswa Biologi Kelas A angkatn 2014 IKIP Budi Utomo Malang." 


\section{METODOLOGI PENELITIAN}

Jenis penelitian ini merupakan penelitian tindakan kelas (PTK) dengan rancangan yaitu berupa pemberian tindakan pada siklus-siklus pembelajaran. Menurut Arifin (2010:190), penelitian tindakan kelas merupakan salah satu bagian dari penelitian tindakan dengan tujuan untuk memperbaiki atau meningkatkan mutu praktik proses belajar mengajar di kelas atau di luar kelas.

Waktu penelitian dilakukan pada bulan Juni s/d Juli 2017 dan lokasi penelitian di Program Studi Pendidikan Biologi IKIP Budi utomo Malang. Penelitian terdiri dari 2 siklus (satu siklusnya dua kali tatap muka) dan waktu penelitiannya pada hari Kamis tanggal 15 dan 22 Juni 2017 untuk siklus I, sedangkan hari Kamis tanggal 6 Juli dan 13 Juni 2017 untuk siklus II.

Subyek penelitian adalah Mahasiswa Semester VI kelas A program studi pendidikan Biologi IKIP Budi Utomo Malang semester genap 2016/2017 yang berjumlah 38 mahasiswa.

Peneliti berperan sebagai perencana, pelaksana, pengumpul data, penafsir data dan pelapor hasil penelitian (Moleong, 2004:186). Selain itu peneliti juga berperan sebagai penyusun media pembelajaran, pelaksana tindakan dan pelaksana wawancara.

Peneliti berkolaborasi dengan 1 dosen pengampuh matakuliah yang bertindak sebagai observer dan dibantu oleh 4 observer mahasiswa yang ikut mencatat tingkah laku mahasiswa selama berlangsungnya kegiatan belajar.
Proses pengumpulan data dilaksanakan dalam waktu 2 bulan, yaitu pada bulan Juni-Juli 2017. Adapun kegiatan-kegiatan yang dilakukan dalam kurun waktu tersebut adalah melaksanakan pembelajaran di kelas dalam 2 siklus, melakukan observasi atas keaktifan mahasiswa dalam PBM, dan melaksanakan tes formatif pada setiap akhir siklus.

Analisis data hasil belajar digunakan untuk melihat prestasi belajar mahasiswa pada setiap akhir pembelajaran atau siklus, sehingga diperoleh gambaran perubahan atau peningkatan hasil belajar kognetif mahasiswa. Proses pengambilan data dilakukan melalui tes tertulis dengan materi DNA, RNA dan Sintesis Protein.

Teknik analisis data yang digunakan adalah deskriptif persentase. Data hasil penelitian yang dianalisis meliputi rata-rata hasil belajar kognetif mahasiswa, ketuntasan belajar individu, dan ketuntasan belajar klasikal.

Guna mengukur ketuntasan belajar individu, peneliti menggunakan rumus oleh Depdiknas (2004:16), sebagai berikut:

$$
\mathrm{NA}=\frac{\mathrm{SB}_{1}+\mathrm{SB}_{2}}{2} \times 100 \%
$$

Keterangan:

NA : Nilai akhir

$\mathrm{SB}_{1}$ : Skor belajar awal mahasiswa (siklus I)

$\mathrm{SB}_{2}$ : Skor belajar akhir mahasiswa (siklus

II)

Sesuai dengan pedoman evaluasi belajar Depdiknas (2004:18), maka kriteria penilaian hasil belajar individu dalam penelitian ini adalah, sebagai berikut: 
Tabel 1. Analisis Ketuntasan Belajar Mahasiswa

\begin{tabular}{ccl}
\hline Tingkat Penguasaan & NilaiHuruf & Keterangan \\
\hline$>85$ & $\mathrm{~A}$ & SangatBaik \\
\hline $75-85$ & $\mathrm{~B}$ & Baik \\
\hline $65-74$ & $\mathrm{C}$ & Cukup \\
\hline $50-64$ & $\mathrm{D}$ & Kurang \\
\hline$<50$ & $\mathrm{E}$ & Sangat Kurang \\
\hline
\end{tabular}

Selanjutnya untuk mengukur maupun klasikal, peneliti melakukan ketuntasan belajar klasikal, peneliti penilaian atau penskoran dengan mencanmenggunakan rumus (Depdiknas, 2004:18), tumkan standar keberhasilan belajar. Sistem sebagai berikut:

$$
\mathrm{KB}=\frac{\mathrm{FN}}{\sum \mathrm{N}} \times 100 \%
$$

Keterangan:

KB : Ketuntasan belajar klasikal

FN : Jumlah mahasiswa tuntas

$\sum \mathrm{N}$ : Jumlah seluruh mahasiswa

Adapun untuk menentukan ketuntasan belajar, baik ketuntasan belajar individu

penilaian menggunakan sistem belajar tuntas (mastery learning), yaitu mahasiswa berhasil atau tuntas belajar bila mencapai nilai penguasaan materi minimal 65 , sedangkan indikator pencapaian ketuntasan klasikal ditentukan pada pencapaian materi secara klasikal $80 \%$. Jika ketuntasan klasikal minimal $80 \%$ telah tercapai maka pemberian tindakan pembelajaran dapat dihentikan (Depdiknas, 2004:18).

Tabel 2. Persentase Ketuntasan Kasikal Hasil Tes Siklus I

\begin{tabular}{|c|c|c|c|c|}
\hline Nilai & $\mathbf{N}$ & Persentase & Akumulasi & T/TT \\
\hline$>85$ & 5 & $13 \%$ & $13 \%$ & \multirow{3}{*}{27 mahasiswa tuntas } \\
\hline $75-85$ & 9 & $24 \%$ & $24 \%$ & \\
\hline $65-74$ & 13 & $34 \%$ & $34 \%$ & \\
\hline $50-64$ & 6 & $16 \%$ & - & \multirow{2}{*}{$\begin{array}{l}11 \text { mahasiswa tidak } \\
\text { tuntas }\end{array}$} \\
\hline$<50$ & 5 & $13 \%$ & - & \\
\hline Total & 38 & $100 \%$ & $71 \%$ & \\
\hline
\end{tabular}

\section{HASIL DAN PEMBAHASAN}

Hasil penelitian berupa paparan data hasil pembelajaran tiap akhir siklus. Masingmasing tindakan itu memaparkan tentang: 1) Hasil belajar kognetif mahasiswa dan analisis ketuntasan belajar klasikal tiap siklus, dan 2) Keaktifan mahasiswa dalam proses belajar mengajar pada tiap siklus. Adapun rincian penyajian hasil penelitian seperti Tabel 2.

Berdasarkan data pada Tabel 2 di atas, diketahui ketuntasan belajar klasikal siklus I mencapai $71 \%$. Secara umum dapat disimpulkan hasil penelitian tindakan kelas siklus I termasuk 'Cukup Baik' karena 71\% mahasiswa tuntas belajar, di mana 27 mahasiswa yang tuntas dan 11 mahasiswa tidak tuntas. Namun persentase tersebut belum mampu mencapai target ketuntasa sedangkan target ketuntasan klasikal minimal yang $80 \%$ mahasiswa tuntas belajar, oleh karena itu peneliti melanjutkan tindakan pada siklus II. 
Tabel 3. Hasil Observasi Keaktifan Mahasiswa Siklus I

\begin{tabular}{|c|c|c|}
\hline \multirow{2}{*}{ AspekAktivitas } & \multicolumn{2}{|c|}{ Jumlah Mahasiswa } \\
\hline & Aktif & TidakAktif \\
\hline Bertanya & 16 mahasiswa $(42 \%)$ & 22 mahasiswa $(58 \%)$ \\
\hline Menjawabpertanyaan guru & 28 mahasiswa $(74 \%)$ & 10 mahasiswa $(26 \%)$ \\
\hline Mengemukakan ide-ide & 11 mahasiswa $(29 \%)$ & 27 mahasiswa $(71 \%)$ \\
\hline Menguraikanmateri & 17 mahasiswa $(45 \%)$ & 21 mahasiswa $(55 \%)$ \\
\hline Menyimpulkanmateri & 12 mahasiswa $(32 \%)$ & 26 mahasiswa $(68 \%)$ \\
\hline Rata-rata & 16.8 & 21.2 \\
\hline Rata-rata persentase & $44.21 \%$ & $55.79 \%$ \\
\hline
\end{tabular}

Berdasarkan data yang tercantum pada Tabel di atas, dapat disimpulkan bahwa selama kegiatan pembelajaran, mahasiswa kurang aktif. Rata-rata persentase mahasiswa yang tidak aktif lebih tinggi $(55,79 \%)$ dibandingkan dengan rata-rata persentase mahasiswa yang aktif $(44,21 \%)$. Hal ini disebabkan karena masih banyak mahasiswa yang kurang aktif dalam bertanya, mengemukakan ide-ide, menguraikan materi, maupun me- nyimpulkan materi pembelajaran, karena mahasiswa terlihat masih-masih ragu-ragu, takut atau malu untuk melakukannya sebab guru tidak menunjuk salah satu mahasiswa untuk bertanya, mengemukakan ide, menguraikan materi, maupun untuk menyimpulkan materi, jadi mahasiswa secara mandiri diminta melakukannya menurut kesadaran, permasalahan, dan inisiatif mereka sendiri.

Tabel 4. Persentase Ketuntasan Kasikal Hasil Tes Siklus II

\begin{tabular}{|c|c|c|c|c|}
\hline Nilai & $\mathbf{N}$ & Persentase & Akumulasi & T/TT \\
\hline$>85$ & 7 & $18 \%$ & $18 \%$ & \multirow{3}{*}{$\begin{array}{l}31 \text { mahasiswa } \\
\text { tuntas }\end{array}$} \\
\hline $75-85$ & 12 & $32 \%$ & $32 \%$ & \\
\hline $65-74$ & 12 & $32 \%$ & $32 \%$ & \\
\hline $50-64$ & 5 & $13 \%$ & - & \multirow{3}{*}{$\begin{array}{l}7 \text { mahasiswa } \\
\text { tidak tuntas }\end{array}$} \\
\hline$<50$ & 2 & $5 \%$ & - & \\
\hline Total & 38 & $100 \%$ & $82 \%$ & \\
\hline
\end{tabular}

Berdasarkan data yang tercantum pada Tabel 4, diketahui ketuntasan belajar klasikal siklus II mencapai $82 \%$ dengan jumlah 31 mahasiswa yang tuntas dan tidak tuntas berkurang menjadi 7 mahasiswa. Berdasarkan hasil belajar mahasiswa tersebut, maka dapat disimpulkan bahwa pelaksanaan tindakan siklus II pada mahasiswa kelas A angkatan 2014 IKIP budi Utomo Malang telah berhasil, di mana persentase ketuntasan belajar klasikal mencapai $82 \%$. Persentase ketuntasan ini telah melewati standar ketuntasan klasikal minimal $80 \%$, dengan telah tercapainya hasil tersebut maka penelitian ini dihentikan.

Tabel 5. Hasil Observasi Keaktifan Mahasiswa Siklus II

\begin{tabular}{|c|c|c|}
\hline \multirow{2}{*}{ AspekAktivitas } & \multicolumn{2}{|c|}{ JumlahMahasiswa } \\
\hline & Aktif & TidakAktif \\
\hline Bertanya & 24 mahasiswa $(63 \%)$ & 14 mahasiswa $(37 \%)$ \\
\hline Menjawabpertanyaan guru & 33 mahasiswa $(87 \%)$ & 5 mahasiswa $(13 \%)$ \\
\hline Mengemukakan ide-ide & 17 mahasiswa $(45 \%)$ & 21 mahasiswa $(55 \%)$ \\
\hline Menguraikanmateri & 22 mahasiswa $(58 \%)$ & 16 mahasiswa $(42 \%)$ \\
\hline Menyimpulkan materi & 15 mahasiswa $(39 \%)$ & 23 mahasiswa $(61 \%)$ \\
\hline Rata-rata & 22.2 & 15.8 \\
\hline Rata-rata persentase & $58.42 \%$ & $41.58 \%$ \\
\hline
\end{tabular}


Berdasarkan Tabel 5, diketahui pada siklus II, aktivitas mahasiswa dalam proses pembelajaran semakin membaik dan meningkat. Kondisi ini ditandai oleh ratarata persentase mahasiswa yang aktif mencapai $58,42 \%$ dan rata-rata persentase mahasiswa yang tidak aktif dalam pembelajaran hanya mencapai $41,58 \%$. Hal ini dikarenakan rata-rata mahasiswa sudah memiliki motivasi dan keberanian untuk bertanya, mengemukakan ide, menguraikan materi, maupun untuk menyimpulkan materi dengan keinginan sendiri, serta mahasiswa dapat menjawab atau menyelesaikan tugastugas yang diberikan oleh guru dengan baik.

Setelah melaksanakan pembelajaran Biologi pada mahasiswa Biologi kelas A angkatan 2014 IKIP Budi Utomo Malang dengan media karikatur berbasis sparkol video scribe pada akhir siklus I dilaksanakan evaluasi pembelajaran. Perolehan nilai ratarata mahasiswa siklus I adalah 68 , di mana nilai tertinggi yang diraih mahasiswa adalah 95, sedangkan nilai terendah yang diperoleh mahasiswa adalah 35. Perolehan ketuntasan belajar klasikal pada siklus I adalah sebesar $71 \%$. Secara umum dapat disimpulkan bahwa hasil penelitian tindakan kelas pada siklus I, untuk ketuntasan secara klasikal termasuk ke dalam kategori 'Cukup' karena mampu mencapai $71 \%$, namun persentase tersebut belum mampu mencapai sedangkan target ketun-tasan klasikal minimal yang 80\% mahasiswa tuntas belajar, oleh karena itu peneliti melanjutkan tindakan pada siklus II.

Rendahnya tingkat ketuntasan belajar klasikal pada siklus I antara lain disebabkan oleh beberapa kendala dalam diri mahasiswa, yaitu berkaitan dengan aktivitas mahasiswa dalam proses belajar mengajar, di mana mahasiswa kurang aktif dalam pembelajaran. Banyak di antara mahasiswa yang masih memiliki keraguan untuk bertanya, menge- mukakan ide, menguraikan materi, maupun untuk menyimpulkan materi. Merujuk pada data hasil observasi aktivitas mahasiswa dalam proses belajar mengajar siklus I, dapat disimpulkan bahwa selama kegiatan pembelajaran, mahasiswa kurang aktif. Rata-rata persentase mahasiswa yang tidak aktif lebih tinggi $(55,79 \%)$ dibandingkan dengan ratarata persentase mahasiswa yang aktif (44,21\%). Hal ini disebabkan karena masih banyak mahasiswa yang kurang aktif dalam bertanya, mengemukakan ide-ide, menguraikan materi, maupun menyimpulkan materi pembelajaran, karena mahasiswa terlihat masih-masih ragu-ragu, takut atau malu untuk melakukannya sebab guru tidak menunjuk salah satu mahasiswa untuk bertanya, mengemukakan ide, menguraikan materi, maupun untuk menyimpulkan materi, jadi mahasiswa secara mandiri diminta melakukannya menurut kesadaran, permasalahan, dan inisiatif mereka sendiri, sehingga peneliti berkesim-pulan bahwa tindakan lanjutan harus diberi-kan pada mahasiswa melalui pelaksanaan pembelajaran siklus II.

Pembelajaran pada siklus II dilaksanakan dalam 2 kali pertemuan. Materi pembelajaran pada siklus II merupakan lanjutan dari materi pembelajaran siklus I, namun dengan sub materi berbeda yaitu sintesis protein. Evaluasi terhadap hasil belajar mahasiswa diberikan pada akhir pembelajaran siklus II. Perolehan nilai ratarata mahasiswa pada siklus II adalah 73,6, di mana sebanyak tiga mahasiswa memperoleh nilai tertinggi yaitu 95, sedangkan nilai terendah adalah 45 dan hanya diperoleh oleh dua orang mahasiswa. Perolehan ketuntasan belajar klasikal pada siklus II mengalami peningkatan dari $71 \%$ pada siklus I meningkat menjadi $82 \%$ (data lengkap dapat dilihat pada Lampiran 2). Sampai pada tahap pembelajaran siklus II, sebanyak 31 
mahasiswa memperoleh nilai minimal 65 dari total 38 mahasiswa. Secara umum dapat disimpulkan bahwa hasil penelitian tindakan kelas pada siklus II, untuk ketuntasan secara klasikal termasuk ke dalam kategori 'Baik' karena mampu mencapai $82 \%$. Persentase ketuntasan ini telah melewati standar ketuntasan klasikal minimal $80 \%$, dengan telah tercapainya hasil tersebut maka penelitian ini dihentikan. Peningkatan ketuntasan belajar mahasiswa pada siklus II antara lain disebabkan oleh meningkatnya aktivitas mahasiswa dalam proses belajar mengajar, di mana beberapa mahasiswa yang kurang aktif dalam pembelajaran pada siklus I dapat secara aktif berpartisipasi, misalnya dengan bertanya, mengemukakan ide-ide, menguraikan materi, maupun menyimpulkan materi pembelajaran.

Selama pelaksanaan pembelajaran pada siklus I dan siklus II, dari hasil pengamatan dapat diketahui telah terjadi perubahan pada mahasiswa ke arah yang lebih baik, karena pada pembelajaran Biologi konsep DNA dan RNA dengan media karikatur berbasis sparkol video scribe telah terjadi proses belajar mengajar yaitu "suatu kegiatan pembelajaran yang menghasilkan suatu interaksi antara mahasiswa dengan guru dalam mencapai suatu tujuan pembelajaran" (Sudjana, 2005), yang mana tujuan utama dari pelaksanaan pembelajaran di sini adalah untuk meningkatkan hasil belajar mahasiswa. Meningkatnya hasil belajar mahasiswa tersebut tentu saja dipicu oleh dengan media karikatur berbasis sparkol video scribe diterapkan dalam proses belajar mengajar, sehingga dapat meningkatkan pemahaman materi dan aktivitas mahasiswa dalam proses belajar mengajar. Berdasarkan hasil penelitian dan rangkaian uraian pembahasan di atas, maka dapat disimpulkan bahwa dengan media karikatur berbasis sparkol video scribe dapat meningkatkan hasil belajar Biologi mahasiswa kelas A angkatan 2014 IKIP budi Utomo Malang.

\section{KESIMPULAN DAN SARAN}

Berdasarkan uraian bahasan di atas dapat disimpulkan bahwa dengan media karikatur berbasis sparkol video scribe yang diterapkan pada mahasiswa kelas A angkatan 2014 Pendidikan Biologi IKIP Budi Utomo Malang pada matakuliah Genetika dengan sub DNA, RNA dan sitesis protein dapat meningkatkan hasil belajar mahasiswa. Peningkatan ini terjadi pada aspek kognitif, peningkatan hasil belajar pada aspek kognitif ditandai dengan adanya peningkatan presentase ketuntasan belajar klasikal pada siklus I sebesar $71 \%$ dengan jumlah mahasiswa yang tuntas sebanyak 27 orang dan meningkat pada siklus II sebesar $82 \%$ dengan jumlah mahasiswa yang tuntas sebanyak 31 orang. Jadi peningkatan hasil belajar pada aspek kognitif mahasiswa dari siklus I dan siklus II meningkat sebesar $11 \%$.

Berdasarkan hasil penelitian tindakan pada mahasiswa kelas A angkatan 2014 Pendidikan Biologi IKIP budi Utomo Malang, maka dapat dikemukakan saransaran, yaitu:

1) Bagi mahasiswa

a. Diharapkan agar mahasiswa selalu memperhatikan anjuran guru dan melaksanakan tugas dengan baik guna meningkatkan hasil belajar.

b. Diharapkan agar mahasiswa lebih disiplin dalam memanfaatkan waktu, terutama waktu untuk belajar, baik saat berada di kelas maupun di luar kelas, misalnya selalu aktif dalam mencari informasi-informasi terkini mengenai aspek-aspek pembelajaran guna meningkatkan pengetahuan, pemahaman, dan hasil belajar sehingga menjadi lebih baik lagi. 
2) Bagi Dosen

Hasil penelitian menunjukkan bahwa dengan media karikatur berbasis sparkol video scribe yang diterapkan dalam penelitian ini mampu meningkatkan hasil belajar Biologi konsep klasifikasi makhluk hidup pada mahasiswa kelas A angkatan 2014 Pendidikan Biologi IKIP budi Utomo Malang, maka disarankan kepada dosen agar menggunakan dengan media karikatur berbasis sparkol video scribe dalam proses belajar mengajar Biologi, khususnya untuk konsep sintesis protein.

3) Bagi peneliti serupa

Diharapkan penggunaan subjek dalam jumlah yang lebih besar dan divariasikan dengan kelompok control bagi peneliti yang meneliti masalah serupa sehingga dapat diketahui hasil penelitian yang lebih baik lagi.

\section{RUJUKAN}

Anonim. 2008. Kromosom. (Online), (http:www.google.co.id/=http://kromos om.files. wordpress.com/2008, diakses 23 Februari 2013.

Ariyanto. 2006. Pengolahan Data Statistik dengan SPSS 14. Jakarta: Salemba Infotek.

Arnyana, I.B.P. 2004. Pengembangan Perangkat Model Belajar Berdasarkan Masalah Dipandu Strategi Kooperatif serta Pengaruh Implementasinya terhadap Kemampuan Berpikir Kritis dan Hasil Belajar Siswa Sekolah Menengah Atas pada Pelajaran Ekosistem. Disertasi tidak diterbitkan. Malang: Universitas Negeri Malang.

BSNP, 2006. Badan standarisasi Nasional Pendidikan. Jakarta: Dekdikbud.

Depdiknas. 2004. Pedoman Khusus Pengembangan Silabus dan Penilaian.
Jakarta: Departemen Pendidikan

Nasional, Direktorat Jenderal

Pendidikan Dasar dan Menengah.

Ennis, R.H. 1992. Critical Thinking Assesment. Journal Theory and Practice. 32(3) Summer 1993. Ohio: Ohio State University.

Friedrichsen, P.M. 2001. A Biology Course for Prospective Elementary Teachers. The American Biology Teacher. Vol. $63(8)$ : 562-568.

Furchan Arief. 1982. Pengantar Penelitian dalam Pendidikan. Surabaya: Usaha Nasional.

Hart, D. 1994. Authentic Assesment A Hand Book for Educators. New York: Addison-Wesley Publishing Company. Mahanal, S. 2009. Pengembangan Perangkat Pembelajaran Deteksi Kualitas Sungai Dengan Indikator Biologi Berbasis Konstruktivistik Untuk Memberdayakan Berpikir Kritis Dan Sikap Siwa SMA Terhadap Ekosistem Sungai Di Malang. Malang: Universitas Negeri Malang.

Nasir, M. 2005. Metode Penelitian. Bogor: Ghalia Indonesia.

Sudjana, Nana. 2005. Penilaian Hasil Proses Belajar Mengajar. Bandung: Remaja Rosdakarya.

Sudijono, A. 2006. Pengantar Evaluasi Pendidikan. Jakarta: Raja Grafindo Persada.

Sugiyono. 2003. Statistik untuk Penelitian. Bandung: Alfabeta.

Surapranata, S. 2004. Analisis Validitas, Reliabilitas, dan Interpretasi Hasil Tes Implementasi Kurikulum 2004. Bandung: Remaja Rosda Karya.

Widodo dan Jasmadi. 2008. Panduan menyusun Bahan Ajar. Jakarta: PT Elex Media Komputindo 